\title{
Agrarian business development in accordance with the national economic and social development plan of SMEs in Thailand
}

\author{
Pisit Potjanajaruwit ${ }^{1, *}$ \\ ${ }^{1}$ FMS, Suan Sunandha Rajabhat University, 1 U-Thong Nok rd, 10200, Dusit, Bangkok, Thailand
}

\begin{abstract}
The purpose of this research was to study the impact of the business environment on business development of SMEs in accordance with the National Economic and Social Development Plan of Thailand. The data was collected from 420 entrepreneurs of SMEs in Thailand using stratified random sampling. A questionnaire was the study's data collection tool while multiple correlation analysis and multiple regression analysis were used with the statistics for data analysis. The results showed that most of the entrepreneurs were males aged 41-50 years, married, and had a bachelor's degree or higher for education. Most SMEs were partnership businesses dealing with agricultural products with a duration of operation between 10-15 years. Most had registered capital of less than 5 million baht with an average annual income of less than 5 million baht and a number of employees fewer than 20 people. According to the national economic and social development plan for these SMEs, there was one particular business environment factor like technology that showed a relationship and a positive impact on overall business development. When considered in each aspect, it was found that (1) technology was related to and had a positive impact on business development in marketing knowledge and (2) technology was related to and had a positive impact on the development in business management.
\end{abstract}

\section{Introduction}

The economic development of Thailand had been a continuous progess though in the past operations may have lacked proper coordinated patterns and certain goals. In most cases, the work was done in favor of solving immediate dilemmas and there were also many government agencies in charge that could sometimes cause work duplication between the departments which could cause unnecessary investment from the national budget. This was one of the reasons that drove the government to find a way to solve the ongoing problems, by developing a systematic plan known as the National Economic and Social Development Plan of Thailand. The first national plan was announced in 1961, and since then there have been releases of 5-year development plans until the present. The country's economic development according to the National Economic and Social Development Plan, although the objectives may be varied, they were all aimed to solve several crucial

*Corresponding author: Pisit.po@ssru.ac.th 
problems such as career development and income of people in the country, especially the small and medium-sized enterprises (SMEs) which became more promoted and fully supported by the government [1]. In the business world in this globalized era, the number of SMEs has tended to increase rapidly due to the emergence of new marketing opportunities that enable solid opportunities for specialized businesses as they have more advantages in economical capital, technology, and production scale from the use of production capacity and technology at their full potential. The cause of the growth of SMEs in the economic system is due to the advancement of various technologies, making small and medium-sized enterprises able to perform certain types of tasks with ease, including distributing products to consumers thoroughly and being more flexible in responding to the needs of customers, resulting in easy and successful entries of the SMEs into the international market. With telecommunications, the distance between people around the world is made closer, so many SMEs could easily step into international business [2]. However, the global economic crisis also affects Thailand, thus forcing SMEs to face management problems and obstacles. Therefore, entrepreneurs of SMEs need to have knowledge about factors in the business environment both inside and outside that may affect the development of operations and business survival. They should also be prepared for various risks that may occur in order to relieve the possible cause of each opportunity which may help the organization to buffer the damage, so that the level of risk and the size of the risk that may occur in the future lower to the organization's acceptable level by mainly taking into account the accomplishment of the objectives or goals of the organization and the types of risk they may encounter [3].

Due to the aforementioned circumstances, it was intriguing to research business development in accordance with the National Economic and Social Development Plan of SMEs in Thailand by focusing on how the business environment would affect their business development, and which the results from the research can be used as a guideline for development to improve operational processes to create successful business opportunities.

\section{Methodology}

This research on business development in accordance with the National Economic and Social Development Plan of SMEs in Thailand is a quantitative research. The study explored executives and entrepreneurs who were involved in business development according to the National Economic and Social Development Plan of SMEs in Thailand. This was a survey research in which questionnaires were used to study the influence of the business environment such as economic, political, and legal environments, technology, and culture that may affect business development according to the National Economic and Social Development Plan in terms of production, marketing, finance and accounting, and management. The processes of the study were as follows:

\subsection{Determination of population and sample groups}

This research on business development in accordance with the National Economic and Social Development Plan of SMEs in Thailand has a studied population of 1,384 executives and entrepreneurs involved in business development covering all eight regions of Thailand. The population was then sampled using Nahmias's Probability Sampling, Stratified Random Sampling technique, and Krejcie and Morgan Sampling Table [4]. The sampled population were executives and entrepreneurs of SMEs that disclosed information to the Office of Small and Medium Enterprises Promotion. The calculated sample size turned out to be 300 samples, but to reserve more proportion or reduce discrepancies in questionnaire answers, the researcher therefore added an approximation of the response rate $(0.4)$ of the 
sample group, resulting in the total sample number of 420 samples required $\{(300 * 0.4)+$ $300\}$ [5].

Table 1. Population size, SMEs entrepreneurs in the sample group and questionaire respondents who disclosed their information to the Office of Small and Medium Enterprises Promotion as classified by regions [6].

\begin{tabular}{|l|c|c|c|}
\hline $\begin{array}{c}\text { SMEs Entrepreneurs in 8 regions of Thailand } \\
\text { (who disclosed data) }\end{array}$ & $\begin{array}{c}\text { Population } \\
\text { Size }\end{array}$ & Sample & Percentage \\
\hline (1) Entrepreneurs in Bangkok & 934 & 284 & 67.62 \\
\hline $\begin{array}{c}\text { (2) Entrepreneurs in Bangkok's Metropolitan } \\
\text { Area }\end{array}$ & 262 & 80 & 19.05 \\
\hline (3) Entrepreneurs in Central Region & 31 & 9 & 2.14 \\
\hline (4) Entrepreneurs in Western Region & 7 & 2 & 0.48 \\
\hline (5) Entrepreneurs In Eastern Region & 41 & 12 & 2.86 \\
\hline (6) Entrepreneurs In Northeastern Region & 23 & 7 & 1.67 \\
\hline (7) Entrepreneurs In Northern Region & 44 & 13 & 3.09 \\
\hline (8) Entrepreneurs in Southern Region & 42 & 13 & 3.09 \\
\hline Total number & $\mathbf{1 , 3 8 4}$ & $\mathbf{4 2 0}$ & $\mathbf{1 0 0}$ \\
\hline
\end{tabular}

\subsection{Questionnaire Quality Assessment}

The quality assessment of the questionaire in terms of content validity, for the inclusivity of the questionaire, its appropriateness, and its linguistics were appraised by 5 experts. It was found that the content validity of the questionnaire was $70 \%$ or greater with IOC of 0.70 1.00 , which is based on the criteria used to judge the content accuracy, so the calculated value must be greater than or equal to 0.50 (IOC $\geq 0.50$ ). The quality of the questionaire was also assessed through the analysis of Internal Consistency Reliability, using the Cronbach's Alpha coefficient, which was found that the observable variable had the lowest alpha coefficient of 0.70 , while observed variables with the highest alpha coefficient had 0.87 . All of the 13 observed variables used in this research were found with alpha coefficients of between $0.70-0.87$ which was in acceptable range. The results of the analysis were consistent with the results of content validity as the questionnaire used had been modified according to the recommendations of experts and had been used in an experiment with a sample group of 30 peoples who were not the sample group in this study. Therefore, the observable variables were accurate in content and suitable for use in analysis to answer research questions [7].

\subsection{Data analysis}

Analysis was done on the opinions about the business environment that affect business development according to the National Economic and Social Development Plan of SMEs entrepreneurs in Thailand in each area to find mean and standard deviation. Data was presented in a tabular format along with a briefing, while testing of the relationship and impact of the business environment and business development according to the National Economic and Social Development Plan of SMEs in Thailand was done using Multiple Correlation Analysis and Multiple Regression Analysis [8]. 


\section{Result}

The results of analysis on opinions about business development according to the National Economic and Social Development Plan as a whole and in the aspect of SMEs entrepreneurs in Thailand revealed these;

Table 2. Level of business development according to the National Economic and Social Development Plan as a whole and in the aspect of SMEs entrepreneurs in Thailand.

\begin{tabular}{|l|c|c|c|}
\hline \multicolumn{1}{|c|}{ Aspects of Development } & $\bar{X}$ & S.D. & Agreement Level \\
\hline 1. Strategies and Planning & 4.27 & 0.64 & High \\
\hline 2. Production & 4.30 & 0.62 & High \\
\hline 3. Marketing & 4.47 & 0.55 & High \\
\hline 4. Financial and Accounting & 4.33 & 0.61 & High \\
\hline 5. Management & 4.29 & 0.55 & High \\
\hline \multicolumn{1}{|c|}{ Overall } & $\mathbf{4 . 3 3}$ & $\mathbf{0 . 2 8}$ & High \\
\hline
\end{tabular}

It was found that most entrepreneurs also agreed on the overall business development at a high level $(\bar{X}=4.33)$. When considered in each aspect, their agreement was found at a high level in all aspects which, when arranged from the highest to the lowest, the first 3 aspects were: market knowledge $(\bar{X}=4.47)$, financial and accounting knowledge $(\bar{X}=4.33)$, and production knowledge $(\bar{X}=4.30)$.

The correlation analysis of business environment and business development according to the National Economic and Social Development Plan of SMEs in Thailand revealed;

Table 3. Correlation analysis of business environment and overall business development of SMEs in Thailand.

\begin{tabular}{|c|c|c|c|c|c|c|}
\hline Variables & DECO & EC & PL & TE & CU & VIF \\
\hline $\bar{X}$ & 4.33 & 4.45 & 4.34 & 4.42 & 4.24 & \\
\hline S.D. & 0.28 & 0.56 & 0.70 & 0.58 & 0.69 & \\
\hline DECO & & $0.056^{*}$ & $0.079^{*}$ & $0.249^{*}$ & $0.046^{*}$ & \\
\hline EC & & & $0.104^{*}$ & $0.044^{*}$ & $0.054^{*}$ & 1.017 \\
\hline PL & & & & $0.129^{*}$ & $0.001^{*}$ & 1.030 \\
\hline TE & & & & & $0.054^{*}$ & 1.023 \\
\hline CU & & & & & & 1.006 \\
\hline
\end{tabular}

Statistical significance at the level of 0.05 .

The independent variables were found to be correlated overall, which may cause problems such as multicollinearity. Therefore, multicollinearity was tested using VIF which the result showed that the VIF of the independent variables of business environment had a value between 1.006-1.030, indicating each independent variable was not correlated. This should not lead to any problems due to internal relationships between independent variables. This is consistent with the research of Neter Wasserman and Kutner (Ussahawanitchakit. 2002: 58-70; citing Neter Wasserman and Kutner 1996: 62-80), that when considering the correlation coefficient between each independent variable and the dependent variable, it was found that the independent variable had positive relationships with dependent variables with the correlation coefficient between 0.001-0.249 with statistical significance at the level of 0.05 . The researcher then analyzed the multiple regression. As shown in Table 4. 
Table 4. Overall Business Development.

\begin{tabular}{|l|c|c|c|}
\hline \multirow{2}{*}{ Independent Variables } & \multicolumn{2}{|c|}{ Overall Business Development } & \multirow{2}{*}{ p-value } \\
\cline { 2 - 4 } & Regression coefficient & Standard Deviation & \multirow{2}{*}{0.653} \\
\hline 1. Economics & 2.469 & 0.055 & 0.624 \\
\hline 2. Politics and laws & 2.158 & 0.044 & $0.032^{*}$ \\
\hline 3. Technology & 0.114 & 0.053 & 0.776 \\
\hline 4. Social Culture & 1.243 & 0.044 & \\
\hline \multicolumn{2}{|c|}{$\mathrm{R}=0.260 \quad$ Adjusted $\mathrm{R}^{2}=0.021 \quad \mathrm{SE}_{\text {est }}=0.276 \quad \mathrm{a}=3.896 \quad \mathrm{~F}=1.449$} \\
\hline
\end{tabular}

* Statistical significance at the level of 0.05 .

It was found that the business environment in the aspect of technology (TE) had a relationship and a positive impact on overall business development (DECO) with statistical significance at the level of 0.05 . Therefore, the 1st hypothesis for the business environment was accepted. On the contrary, economy (EC), Politics and Law (PL) and social cultural (CU) showed no relationship.

The results of the multiple regression analysis found that the business environment in the aspect of technology (TE) was a predictor of overall business development credibility (DECO). Therefore, a predictive equation was created by doing a new multiple regression analysis consisting of the above variables with the multiple correlation coefficient of the dependent variable and the independent variable $(\mathrm{R})$ of 0.260 , the Adjusted R2 coefficient of 0.021 , and the standard error (SEest) of 0.276 (Table 27, Annex D). The equation is shown as follows;

$$
\mathrm{DECO}=3.804+0.120 \mathrm{TE}
$$

\section{Discussion}

This research of Business development according to the National Economic and Social Development Plan of SMEs in Thailand can be summarized as follows;

1. Entrepreneurs agreed about the overall business environment and on each and every aspect at a high level. As business environment is a factor that can influence the organization to increase the chances of success or failure in the operation, so it is something that entrepreneurs should not overlook, especially in order to create business advantages and be prepared for the changes in every scenerio - as there can be trade uncertainty with intense competition patterns, changing consumer behavior, legal and tax restrictions, risen interest rates, financial imbalance, social and political issues that create disruption in business development, or even the stability of the government that is an important part in driving business to be more perfect and successful. This is consistent with the study of Mahdavi, G., \& Daryaei, A. A. [9], which explored the relationships and the impact of the internal potential and business environment on the environmentanl management accounting of bunsinesses that received ISO 14001 in EU. The result revealed that business enterpreneurs gave importance to the potential in the organization, the business environment, and the effectiveness of environmentanl management accounting at a high level.

2. Entrepreneurs agreed about overall business development and on each and every aspect at a high level due to the economic and trade changes that modern technology has played an important role in. That is why SMEs need to develop to keep up with economic growth and they must adapt to survive and be stronger to withstand the fierce competition in the future. They need development in the aspect of strategic planning, production, 
marketing, finance and management to use them as important forces to drive the business to move forward with stability and sustainability.

This is consistent with the study of Prajogo, D. I. [2], which explored the potential of community business in the northeastern region of Thailand and found that the significant problems in community business were marketing, management, and lack of funds for which a possible solution was to develop management processes, especially in marketing and finance, adjusting the thinking processes and attitudes of entrepreneurs. Moreover, the support from both public and private sectors must continue to achieve the objectives of the community business development.

The study of Mahdavi, G., \& Daryaei, A. A. [9], which focused on the management problems and solutions for the SMEs in Thailand found that the financial problems included a lack of circulating capital and a lack of accounting systems for good financial planning. Production problems included relatively high turnover of workers who were local workers in the area whose main occupation was being farmers. The labor force had a relatively low level of education, resulting in a lack of skills and knowledge in the workplace, responsibility, perseverance and discipline in the workplace. Human resource problems included lack of labor during the harvest season and lack of qualified labor. There was also no institution to support labor training, and therefore they had to hire skilled workers from other areas resulting in having to pay high wages.

Marketing problems included marketing competition, decreased demand for consumption, and low product quality compared with foreign products. Problems related to accessing government services were that government agencies required complicated procedures resulting in lack of coordination or meetings between the state and young entrepreneurs. There was also a lack of study on the occuring problems to be used as guidelines for finding the solutions. As for the guidelines for solving SMEs' problems according to experts, psychology should be applied in the management. There should also be public relations advocacy from government agencies as well as training on how to create a correct accounting system.

There was a study from Rocha, E. A. G. [10] which explored the characteristics of business management in rural communities that are self-reliant in business, a case study of agricultural cooperatives in the northeast of Thailand which aimed to study the development of rural community organizations that could be self-reliant in business and the characteristics of the components of business management of community organizations. The study was a qualitative research with supporting quantitative data and questions were through interviews. There were 11 committee members interviewed, along with 16 other interviewees who were managers, staff from various departments, or employees. 94 members of a sample were also interviewed along with 2 people who were a district cooperative officer and a cooperative auditor. The study found that cooperatives use a group as an important tool in community economic development. Their business was conducted under the three-legged economy concept, namely capital, production, and marketing. The characteristics of cooperative business management included capital management, production, processing, and marketing management. Therefore, for business management in each area, the cooperative emphasized the learning from on real practice by continually summarizing the lessons combined with modern management done through management procedures, namely decision making, planning, implementation of plans, and control of the audit in which every step shared an intersected process.

3. Business environment in terms of technology showed a positive relationship with the overall business development, knowledge of marketing, and administrative management. As the size of the investment is one of the limitations of SMEs, which is a disadvantage in the development and growth of the business when compared with large businesses, applying new changes through the use of modern technology, especially for SMEs, helps 
reduce costs. Technology can also be used in management both in the working process and document work. It can also be used to increase marketing efficiency to gain a competitive advantage from various forms of information technology, such as using e-mail to communicate with customers and promotions of products and services on websites. It will help expanding marketing channels and can also respond to customer needs more quickly. This is in line with the study of the Bah, E. H., \& Fang, L. [11], which explored the market opportunities for SMEs in Sub-Saharan Africa. It was found that obstacles that limit the marketing of SMEs were partly caused by the national industry promotion policies which focused on having more production for exports than support. The export market, consisting of major industries, had superior potential, therefore not enough importance was given to the development of SMEs to be their supporting industries [13,14].

This caused a lack of supporting link between production and marketing which was also partly a result of the lack of technology in the production process resulting in the products manufactured not meeting the quality requirements and causing the manufacturers to turn to and rely more on imported foreign raw materials. Another factor was due to the distribution channels that were unable to directly reach buyers as trade was made through intermediaries resulting in high costs but low selling price. Furthermore, having the main export market as a large market of only a few countries, when changes occur, such as the economic recession, it may cause change in consumption behavior. Therefore, the market opportunities for SMEs may depend on the role of the government agencies that provide assistance to increase their potential, reduce business limitations, and increase the ability to operate. There must be development in the production of good quality products and access for more buyers in the market.

Suggestions for the use of research findings; 1. Entrepreneurs should focus on the business environment, including economic, cultural, social, political, legal and technological aspects to be used in business development in order to gain more trade advantages. 2. Entrepreneurs should focus on promoting continuous business development, including strategic plans, marketing, production, management, and technology in order to strengthen and sustain the organization. 3. Entrepreneurs should apply the business environment principles in various business development in order to increase the organization's potential and reduce business limitations.

\section{References}

1. F. Hernández-Perlines, E. Mancebo-Lozano, European Journal of Family Business 6(2), 86-98 (2016)

2. D.I. Prajogo, International journal of production Economics 171, 241-249 (2016)

3. E. Bastian, M. Muchlish, Procedia-Social and Behavioral Sciences 65(3), 787-792 (2012)

4. Y. Sheng, Z. Huang, C. Liu \& Z. Yang, Journal of Organizational Behavior 35(6), 851870 (2019)

5. V. Bandurin et al., Montenegrin Journal of Economics 13(1), 171-179 (2017)

6. Office of Small and Medium Enterprises Promotion, Gross Domestic Product of Thai SMEs (2018) https://www.nationthailand.com

7. B. Mrkajic, Technovation 68, 44-55 (2017)

8. J. Zhu, M.R. Chertow, Ecological economics 135, 10-21 (2017)

9. M. Ihnatenko et al., International Journal of Economics and Business Administration VII(2), 290-301 (2019) 
10. E.A.G. Rocha, Procedia Economics and Finance 4, 335-349 (2012)

11. E.H. Bah, L. Fang, 219-Impact of the business Environment on Output and Productivity in Africa 2159 (2015)

12. C. Gaganis, F. Pasiouras, F. Voulgari, Economic Modelling 78, 275-292 (2019)

13. T. Ai, N. Huynh, EUrASEANs 2(3), 40-50 (2017)

14. A. Př́vara, Migration Letter 16(2), 245 - 254 (2019) 